\title{
HUNTER, Richard. The Measure of Homer: The Ancient Reception of the Iliad and Odyssey. Cambridge: Cambridge University Press, 2018.
}

Eduardo da Silva de Freitas

Universidade Federal do Rio de Janeiro (UFRJ/FAPERJ), Rio de Janeiro, Rio de Janeiro / Brasil

Universidade do Estado do Rio de Janeiro (UERJ), Rio de Janeiro, Rio de Janeiro / Brasil eduardosfreitas@gmail.com

https://orcid.org/0000-0002-9771-9913

Em 2018, a Cambridge Univesrity Press publicou The Measure of Homer: The Ancient Reception of the Iliad and Odyssey, de Richard Hunter. O professor, que há muito se dedica ao estudo da literatura dos períodos helenístico e imperial, é referência recorrente em trabalhos acadêmicos no Brasil especialmente com suas obras The New Comedy of Greece and Rome, de 1985 - traduzida para o português em 2010 com o título A comédia nova na Grécia e em Roma - e Tradition and Innovation in Hellenistic Poetry, de 2004, publicada em conjunto com o professor Mario Fantuzzi.

Na publicação de que se trata agora, apesar de o título sugerir o estudo de um amplo arco temporal, Hunter se propõe a seguir algumas apropriações dos poemas homéricos por escritores dos períodos helenístico e imperial. O ponto de partida é a forte influência dos poemas homéricos sobre artistas e críticos da antiguidade para rastrear certos modos de aproveitamento do conjunto épico. $\mathrm{O}$ autor nos mostra como alguns escritores daqueles períodos não só instrumentalizam os torneios linguísticos e as expressões homéricas, mas também estabeleceram debates sobre os valores que julgam representados por certas cenas nas épicas. Trata-se de uma obra de exercício de leitura e interpretação de 
como Homero foi compreendido e incorporado em alguns escritos da antiguidade.

O título é convidativo à leitura, mas, já no início, Hunter esclarece que apenas reúne uma série de estudos sobre a recepção de Homero e reconhece lacunas importantes no seu trabalho que deixa de lado a apropriação de Homero pelo drama grego e pela épica imperial. De todo modo, embora não seja um estudo sobre toda a recepção antiga de Homero, o fato é que inúmeros autores são citados ao longo do livro: do arcaico Hesíodo, até o medieval Eustácio, passando por Platão, Aristarco, Longino e Dio Crisóstomo entre outros. No geral, apesar de a reunião de citações acontecer, por vezes, de forma superficial e açodada, o livro traz uma série de considerações relevantes a respeito de alguns olhares lançados sobre Homero por diferentes poetas e comentaristas da época helenística e imperial.

O livro está dividido em cinco capítulos que, apesar de unificados pela ideia da influência homérica, apresentam andamentos bastante independentes. O primeiro deles, "Placing Homer", tem como ponto de partida o delineamento do perfil solene emprestado a Homero em alguns registros escritos e pictóricos do mundo antigo. Associando Homero aos deuses, ao sol e ao oceano, eles materializam a ideia de onipresença e onipotência do poeta e de seus escritos. Hunter verifica essa influência tanto em algumas inscrições epigramáticas do período helenístico e imperial encontradas pelo mundo de influência grega como em dois discursos de Dio Crisóstomo, Discurso da Eubeia ou o Caçadador, e o Discurso XXXVI. No primeiro caso, ele observa a presença modelar de Homero nos textos, cujos assuntos são trabalhados recorrendo-se às personagens e às formas de expressão típicas dos poemas que servem expediente enobrecedor dos discursos a que são incorporados. Quanto aos textos de Dio, chama a atenção de Hunter o tom moralizante da apropriação de Homero, em que ressuma a prevenção platônica contra a poesia aliada à proposta de substituí-la por relatos mais enobrecedores. É interessante acompanhar com Hunter o contraste dos registros em termos de circulação e produção, além dos diferentes níveis e tipos de diálogo que estabelecem com os poemas homéricos. 
O segundo capítulo, intitulado "Homer and the Divine", trata da recepção do aparato mitológico dos poemas homéricos. Ele se abre com a apresentação das visões sobre os deuses como símbolos ou alegorias dos elementos da natureza e do debate sobre a interferência das divindades nas ações humanas. Ambas as preocupações que irmanam os leitores modernos de Homero a Porfírio, Longino e Plutarco. O tema da morte, presente no capítulo anterior, é retomado agora para que Hunter apresente como a morte era, por vezes, representada nos termos de um convite para a integração à convivência com os deuses, ao que se associava a ideia de admissão do morto num banquete divino nos termos homéricos. Em seguida, depois de argumentar que a noção de grandiosidade que paira entorno de Homero deriva da linguagem hiperbólica da épica, Hunter passa à cena do encontro de Páris, Helena e Afrodite no canto III, da Ilíada, para abordar os elos estabelecidos pelos antigos entre divindade e amor. Recuperando o debate antigo sobre se o amor teria origem humana ou divina, Hunter exibe toda sua erudição para anotar as nuances das representações do amor em poetas, como Apolônio de Rodes, Eurípedes, Hesíodo, Ovídio. O capítulo se encerra com o tratamento da influência da representação dos deuses homéricos sobre os gregos, privilegiando o Discurso Olímpico, de Dio Crisóstomo, com sua abordagem das relações entre poesia e arte figurativa.

O elogio de Odisseu à vida festiva no início do canto IX da Odisseia é mote do terceiro capítulo, "The Golden Verses". Hunter sobrevoa uma miríade de textos, entre os quais estão a República e o Protágoras, de Platão, e $O$ banquete dos sete sábios e Do banquete, de Plutarco, e alguns trechos de Teognis, verificando como aquele fragmento suscitou toda uma discussão posterior sobre o simpósio, em linhas gerais contraposta à ideia expressa por Odisseu de que beber e comer ao som de um aedo é o que há de melhor na vida. Hunter registra como estão presentes nessas obras a exortação de moderação dos participantes dos simpósios, certa indisposição contra a presença da poesia e o respeito aos deuses. No trecho final do capítulo, encontra-se um excurso sobre a narrativa da perspectiva dos antigos, excurso motivado pelas indagações 
de Odisseu $(O d$. IX, 14) sobre por onde começar o relato de suas aventuras.

No quarto capítulo, "Homer among the Scholars", o foco de Hunter são as questões colocadas pelos estudiosos antigos do texto homérico a respeito de lapsos e inconsistências de certas partes dos poemas $\mathrm{O}$ capítulo dá grande destaque às anotações de Aristarco sobre o texto, especialmente a respeito da cena do canto XIV da Ilíada, em que Hera pede auxílio a Afrodite para seduzir Zeus, e a cena do encontro entre Nausicaa e Odisseu no canto VI da Odisseia. Hunter acompanha os argumentos de Aristarco que questiona a autenticidade de certos versos, considerados por ele inverossímeis no conjunto das cenas ou mesmo destoante do que acredita ser o padrão da composição homérica. Além disso, Hunter se volta para a prática frequente entre os autores antigos de retrabalhar os textos homéricos, expandido certas cenas dos poemas ou acrescentando-lhes algo de jocoso/paródico, como fazem Dio Crisóstomo, Filostrato e Luciano e Plutarco. Para terminar o capítulo, Hunter volta ainda uma vez a Longino para explorar a ideia que circulava entre os antigos segundo a qual a Ilíada, com sua forma mais intensa e dramática, seria obra da juventude de Homero, ao passo que a Odisseia, mais narrativa, o seria da velhice.

O capítulo de encerramento do livro, "The Pleasures of Song", é quase todo dedicado a alguns dos desdobramentos que a cena de Odisseu com as Sirenes no canto XII teve nas letras gregas e termina com uma breve análise da cena em que Aquiles aparece tocando lira no canto IX da Ilíada. Após apontar que aquela cena está ligada ao debate antigo a respeito do prazer e da utilidade, Hunter traz o Platão do Fedro, do Teeteto, do Crátilo e d' O Banquete novamente ao primeiro plano, para destacar a crítica do filósofo à poesia, enquanto falsa promessa de conhecimento, e o elogio da dialética como a verdadeira porta de acesso ao conhecimento. A repercussão dessa visão platônica é visitada por Hunter no De Finibus, de Cícero, no Como um jovem deve estudar poesia, de Plutarco, até chegar aos Pais da Igreja, entre os quais está Máximo de Turim, com sua comparação de Odisseu, que se amarrou no 
mastro para salvar sua vida, e Cristo, que se deixou pregar na cruz para salvar humanidade.

Da leitura desse livro de Hunter sai o leitor conhecendo melhor não só a impressão e o impacto que os poemas homéricos causavam entre os antigos, mas também o próprio texto, com suas nuances e complexidades. Nesse sentido, o The Measure of Homer é não só instrutivo sobre a recepção antiga, mas um bom estímulo para mais uma visita aos poemas, que têm suscitado, séculos afora, a imaginação e a reflexão de diversos leitores e escritores.

\section{Referência}

HUNTER, Richard. The Measure of Homer: the Ancient Reception of the Iliad and Odyssey. Cambridge: Cambridge University Press, 2018.

Recebido em: 3 de agosto de 2020. Aprovado em: 5 de outubro de 2020. 